\title{
THE SEARCH FOR AN IMPROVED Lotus pedunculatus FOR HIGH COUNTRY PASTORAL SYSTEMS
}

J.M. KEOGHAN and R.E. BURGESS Invermay Agricultural Centre, MA F, Mosgiel Grasslands Division, DSIR, Palmerston North

\begin{abstract}
Abstraci
The performance of 55 Lotus pedunculatus lines of diverse type and origin was assessed on acid and infertile soils on the East Otago Plateau at 3 sites representing an altitudinal sequence of increasing severity of climate.

Tetraploid lines and lines with Mediterranean parentage were more susceptible to out-of season frosting than theirdiptoid equivalents and tines without Mediterranean parentage. By the 3rd summer, a diploid NZ selection, G4701, showed a good combination of high herbage yields, rhizome spread and tolerance of frosting at all sites. G4701, its tetraploid equivalent, G4702, and a selection from within the cultivar Grasslands Maku for rapid germination at low termperatures produced the highest yields averaged over the 3 sites in the altitudinal sequence. The use of these lines is likely to enhance the role of lotus in tussock grassland pasture systems.
\end{abstract}

Keywords: Maku, G4701, G4702, low temperature germination, frost damage, rhizome spread herbage yield.

\section{INTRODUCTION}

Grasslands Maku Lotus pedunculatus is a valid, lower cost alternative to conventional clovers on moist, acid and infertile tussock grassland soils (Scott \& Mills 1981). Although not bred specifically for this environment (Barclay \& Lambert 1970), it is well suited edaphically to these areas. However, limitations relating to the climatic and agronomic suitability of this tetraploid cultivar in some high country environments and management systems restrict its usefulness. For example, the spread of establishing plants of Maku in tussock grasslands has been found to be severely limited in cold areas and aspects and by grazing during the critical JanuaryMarch period of rhizome spread (Dunbar \& Costello 1985, Wedderburn \& Lowther 1985). Further, observations of Maku on the East Otago Plateau suggest that herbage is susceptible to out-of-season frosting (Mclntosh et al. 1984), so reducing its reliability as stock-piled summer feed on shady faces at mid and upper altitudes in the high country.

Of all the legumes, lotus is one of the slowest to establish (Armstrong 1974). Germination rates are reduced compared with red and white clovers, and at temperatures below $10^{\circ} \mathrm{C}$ Maku fails to reach $75 \%$ germination (Hampton et al. this volume). Selections within Maku for low temperature germination have been made and the performance of these selections are reported in this paper.

This paper further reports the herbage yields, plant spread and susceptibility of standing herbage to summer frosting of 55 Lotus pedunculatus lines, including the low temperature germination selections, in a trial at 3 sites on the East Otago Plateau representing an altitudinal sequence of increasing severity of climate.

\section{MATERIALS AND METHODS}

Three sites were chosen in virgin tussock grassland dominated by snow grass, Chionochloa rigida, at Waipori, Castle Dent and Ailsa Craig, each with similar soil and aspect (Table 1).

At each site, the 55 Lotus pedunculatus lines formed part of a trial of 169 lines of a wide range of legume species, arranged in row's in each of 4 replicates in a $13 \times 13$ 
Table 1: Soil and climatic characteristics of three sites representing an altitudinal sequence on the East Otago Plateau.

\begin{tabular}{lccc}
\hline & Waipori & $\begin{array}{c}\text { Lammermoor } \\
\text { Castle Dent }\end{array}$ & $\begin{array}{c}\text { Lammerlaw } \\
\text { Ailsa Craig }\end{array}$ \\
\hline Altitude $(\mathrm{m})$ & $\mathbf{4 6 0}$ & $\mathbf{7 5 0}$ & $\mathbf{1 0 4 0}$ \\
$\mathrm{pH}$ & $\mathbf{4 . 7}$ & $\mathbf{4 . 6 - 4 . 7}$ & $\mathbf{4 . 6}$ \\
Olsen P & $\mathbf{5}$ & $\mathbf{5}$ & $\mathbf{5}$ \\
SO.-S & $\mathbf{9}$ & 8 & $\mathbf{6}$ \\
Rainfall $(\mathrm{mm})$ & 1100 & 1000 & $\mathbf{6 0 0}$ \\
Mean air temperature $\left({ }^{\circ} \mathrm{C}\right)$ & 6.2 & $\mathbf{7 . 2}$ & $\mathbf{6 . 2}$ \\
September-December 1985 & 10.5 & $\mathbf{9 . 6}$ & $\mathbf{6 . 6}$ \\
March-April 1986 & 9.3 & $\mathbf{8 . 2}$ & $\mathbf{7 . 2}$ \\
Mav 1986 & 5.6 & $\mathbf{4 . 5}$ & $\mathbf{3 . 4}$ \\
\hline
\end{tabular}

lattice design to reduce intra-replicate variation. Seedlings inoculated with the recommended strain of Rhizobium were transplanted into the sites during spring/early summer 1983184, in 8-plant rows, $30 \mathrm{~cm}$ between plants, $2 \mathrm{~m}$ between rows, following site mowing and clearing, and selective removal of resident vegetation with glyphosate along a narrow planting strip. The trial areas received basal lime (1.0/ha) and molybdate superphosphate $(250 \mathrm{~kg} / \mathrm{ha}$, supplying $22 \mathrm{~kg} \mathrm{P}$ and $27 \mathrm{~kg} \mathrm{~S} / \mathrm{ha})$ in the first year and maintenance superphosphate $(125 \mathrm{~kg} / \mathrm{ha})$ in the succeeding two years.

Rows were assessed visually for vigour and frost damage, and measurements made of rhizome spread (plant diameter at 4 points chosen at random along each plot) and herbage DM yield (determined from a $30 \mathrm{~cm}$ wide cut along the full $2.4 \mathrm{~m}$ length of each row). The number of harvests varied with site and season from 3 at Waipori, 2 at Castle Dent and 1 in the first full season at Ailsa Craig and 2 in the second (1985186) season.

The 55 L. pedunculatus accessions represented a broad range of types from mild and Mediterranean climatic zones to cool temperate, from NZ (16), Australia(I), Mediterranean and mid-Europe (22), Chile and Argentina (11) and USA (5). The NZ lines included Maku (4n), 2 selections from within Maku for more rapid germination at low temperature $\left(10 / 5^{\circ} \mathrm{C}\right.$ day/night), G4703 (2n) and G4704 (2n) with Mediterranean parentage, and G4701 (2n) and G4702 (4n), selections based only on NZ material. The germination of these NZ lines was tested in the laboratory at fluctuating temperatures.

\section{RESULTS AND DISCUSSION}

Figure 1 shows low temperature germination selections germinate more rapidly than Maku under a $10^{\circ} / 5^{\circ} \mathrm{C}(16 \mathrm{~h}$ day/8 $\mathrm{h}$ night) regime, reaching $75 \%$ germination after about 14 days compared with more than 33 days for Maku. This confirms other reports of the poor germination of Maku at temperatures below $10^{\circ} \mathrm{C}$ (Charlton 1978) and the recommendation that Maku be sown in March for autumn sowings and September/October for spring sowings (Hampton et al. this volume).

If germination rate and seedling vigour are highly correlated, then lotus selections for more rapid germination at low temperatures may haveimplications for the future use of lotus in the high country, since it can be expected to result in an improved level of establishment, especially in the colder areas. However, the improved rates of germination at low temperatures in the laboratory require field confirmation,

The low temperature germination selections have also been found to germinate more rapidly than all other tetraploid and diploid lotus lines tested (Table 2). All diploid Lot us pedunculatus lines were slow, and the tetraploid NZ selection (G4702) is notable for its moderate rate of germination at these low temperatures, without any selection for this particular attribute. 


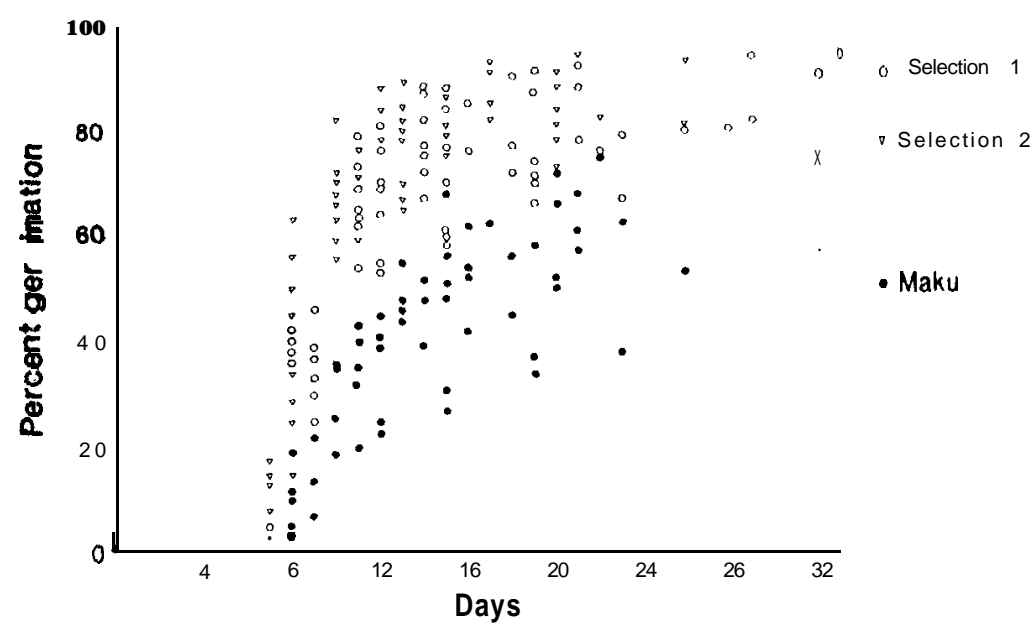

Figure 1: Percent germination of 3 tetraploid lotus lines at $10^{\circ} / 5^{\circ} \mathrm{C}$ day/night.

Table 2: Percent germination of lotus lines at 29 and 46 days, at $8 \% 4^{\circ} \mathrm{C}$ day/night.

$\begin{array}{llcc}\text { Lotus pedunculatus } & & 29 \text { days } & 2.5 \\ \text { G4701 } & (2 \mathrm{n}) & 9.9 & 2.7 \\ \text { G4702 } & (4 n) & 1.8 & 11.7 \\ \text { G4703 } & (2 n) & 0.9 & 111 \\ \text { G4704 } & (2 n) & 4.5 & 3.9 \\ \text { Maku } & (4 n) & 4.0 & 6.7 \\ \text { Selection 1 } & (4 n) & 1.7 & 43.1 \\ \text { Marshfield } & (4 n) & 14.0 & 6.4 \\ \text { Lotus corniculatus } & (2 n) & 235 & 14.6 \\ \text { Franco } & & & 3.39 \\ \text { SED } & \end{array}$

In the altitudinal sequence on the East Otago Plateau, herbage yields for the low temperature germination selection 1, G4701 and G4702 were higher in 1985186 than all other 55 accessions averaged over all sites (Table 3). All 3 lines were in the top 8 at each site. Only two other accessions ranked in the top 10 at each site, namely 5994,

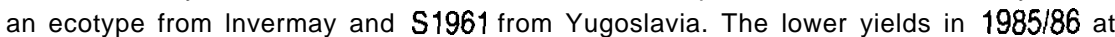
Waipori, the most favourable site, is attributed to a more severe cutting management ( 3 versus 2 cuts at the higher sites), and the almost complete loss of late summer/autumn herbage at Waipori following a severe late autumn frost.

Assessments of out-of-season frost damage (Table 4) indicate that in general cultivars and lines with Mediterranean parentage (G4703, G4704, Maku and low temperature germination selection 2) were significantly more susceptible than those lacking Mediterranean parentage (G4701, G4702). Within each of these groupings, diploid lines were less susceptible to frosting than their tetraploid equivalents (ie G4703 vs Maku; G4701 vs G4702). G4704, the NZ bred cultivar with 3/4 Mediterranean (Portuguese) parentage, has not only shown low tolerance of frosting, but also poor spread (Table 5), and limited productivity, particularly at the two colder sites (Table 3).

None of the 55 cultivars and lines has consistently shown the combined attributes of a high ranking for herbage production at all sites (Table 3), high out-ofseason frost tolerance (Table 4) and at least moderately high spread (Table 5). At the lowest and middle sites, there was a negative correlation between herbage yield and spread $(P<0.05)$, more than two years after transplanting. Very few individual lines 
Table 3: Annual yields of Lotus pedunculatus 1985/86 (kg DM/ha) (3) and ranking for yield (I-55) in 1984/85 (1) and 1965166 (2).

\begin{tabular}{|c|c|c|c|c|c|c|c|c|c|c|}
\hline \multirow[t]{2}{*}{$\begin{array}{l}\text { Cultivar or } \\
\text { line }\end{array}$} & \multicolumn{3}{|c|}{$\begin{array}{l}\text { Waipori } \\
(460 \mathrm{~m})\end{array}$} & \multicolumn{3}{|c|}{$\begin{array}{l}\text { Castle Dent } \\
(750 \mathrm{~m})\end{array}$} & \multicolumn{3}{|c|}{$\begin{array}{c}\text { Ailsa Craig } \\
(1040 \mathrm{~m})\end{array}$} & \multirow[t]{2}{*}{$\begin{array}{l}\text { Overall } \\
\text { Mean }\end{array}$} \\
\hline & (1) & (2) & (3) & (1) & $(2)$ & (3) & (1) & (2) & (3) & \\
\hline $\begin{array}{l}\text { Maku } \\
\text { Maku Selection } 1\end{array}$ & $\begin{array}{r}(20) \\
(5)\end{array}$ & $\begin{array}{l}\text { (7) } \\
(4)\end{array}$ & $\begin{array}{l}3440 \\
3590\end{array}$ & $\begin{array}{l}(45) \\
(10)\end{array}$ & $\begin{array}{r}(15) \\
(1)\end{array}$ & $\begin{array}{l}3930 \\
5520\end{array}$ & $\begin{array}{l}(44) \\
(22)\end{array}$ & $\begin{array}{l}(9) \\
(2)\end{array}$ & $\begin{array}{l}3700 \\
4880\end{array}$ & $\begin{array}{ll}3670 & (8) \\
4660 & (1)\end{array}$ \\
\hline $\begin{array}{l}\text { Maku Selection } 2 \\
\text { G4703 (x NZ) } \\
\text { G4704 ( } x \text { Port.) }\end{array}$ & $\begin{array}{r}(2) \\
(7) \\
(13)\end{array}$ & $\begin{array}{r}(3) \\
(15) \\
\text { (11) }\end{array}$ & $\begin{array}{l}3740 \\
2830 \\
2880\end{array}$ & $\begin{array}{r}(7) \\
(16) \\
(50)\end{array}$ & $\begin{array}{r}(7) \\
(14) \\
(47)\end{array}$ & $\begin{array}{l}4220 \\
3950 \\
3100\end{array}$ & $\begin{array}{l}(42) \\
(45) \\
(55)\end{array}$ & $\begin{array}{c}(271 \\
(1) \\
(54)\end{array}$ & $\begin{array}{l}3120 \\
5010 \\
2190\end{array}$ & $\begin{array}{l}3730(7) \\
3930(4) \\
2800(44)\end{array}$ \\
\hline $\begin{array}{l}\text { G4701 } \\
\text { G4702 }\end{array}$ & $\begin{array}{r}(14) \\
(3)\end{array}$ & $\begin{array}{l}\text { (8) } \\
\text { (1) }\end{array}$ & $\begin{array}{l}3370 \\
4090\end{array}$ & $\begin{array}{r}(1) \\
(11)\end{array}$ & $\begin{array}{l}\text { (3) } \\
\text { (2) }\end{array}$ & $\begin{array}{l}5010 \\
5490\end{array}$ & $\begin{array}{r}(2) \\
(39)\end{array}$ & $\begin{array}{l}(4) \\
(5)\end{array}$ & $\begin{array}{l}4270 \\
3900\end{array}$ & $\begin{array}{ll}4290 & (3) \\
4490 & (2)\end{array}$ \\
\hline $\begin{array}{l}\text { S1928 (Chile) } \\
51961 \text { (Yugoslavia) }\end{array}$ & $\begin{array}{l}(4) \\
(9)\end{array}$ & $\begin{array}{l}(2) \\
(5)\end{array}$ & $\begin{array}{l}3760 \\
3580\end{array}$ & $\begin{array}{l}(36) \\
(40)\end{array}$ & $\begin{array}{c}(42) \\
(8)\end{array}$ & $\begin{array}{l}3340 \\
4130\end{array}$ & $\begin{array}{l}\text { (11) } \\
\text { (12) }\end{array}$ & $\begin{array}{l}\text { (6) } \\
(7)\end{array}$ & $\begin{array}{l}3880 \\
3760\end{array}$ & $\begin{array}{l}3650(9) \\
3660(5)\end{array}$ \\
\hline 51957 (U.K.) & (1) & (6) & 3490 & (8) & (37) & 3400 & (35) & (3) & 4670 & 3860 \\
\hline $\begin{array}{c}5994 \text { (Invermay } \\
\text { ecotype) }\end{array}$ & (15) & (10) & 3050 & $(47)$ & (9) & 4110 & (48) & (10) & 3680 & $3630(10)$ \\
\hline $\begin{array}{l}\text { Bart (Scotland) } \\
\text { Overall mean }\end{array}$ & (35) & (36) & $\begin{array}{l}2320 \\
2530\end{array}$ & (43) & (55) & $\begin{array}{l}2640 \\
3660\end{array}$ & (53) & (51) & $\begin{array}{l}2520 \\
3130\end{array}$ & $\begin{array}{l}2490(55) \\
3110\end{array}$ \\
\hline SED & & & 650 & & & 620 & & & 430 & 850 \\
\hline $\begin{array}{l}\text { Grasslands } \\
\quad \text { cultivars }(7)\end{array}$ & & & 3460 & & & 4440 & & & 4090 & 4000 \\
\hline Others (48) & & & 2390 & & & 3540 & & & 2990 & 2980 \\
\hline SED & & & 200 & & & 190 & & & 260 & 135 \\
\hline
\end{tabular}

Table 4: Out-of-season frost damage in L. pedunculatus. Mean of 4 frosts at Castle Dent over two seasons.

\begin{tabular}{|c|c|c|c|c|c|}
\hline \multicolumn{2}{|c|}{ Cultivar or line } & $\begin{array}{c}\text { Damage } \\
\text { Index (O-3)' }\end{array}$ & \multicolumn{3}{|c|}{ Range of Damage } \\
\hline $\bar{M}^{\prime}{ }^{-}$ & $(4 n)$ & $2.1(55)$ & $1.2 \quad 2.7$ & - & - \\
\hline Selection 1 & $(4 n)$ & $16(36)$ & $0.2=2.5$ & & \\
\hline Selection & $(4 n)$ & $2.0(54)$ & $0.7-2.6$ & & \\
\hline G4703 & $(2 n)$ & $1.5 \quad(29)$ & $0.5 \quad 2.4$ & & \\
\hline G4704 & (2n) & $18(52)$ & $0.7-29$ & & \\
\hline G4701 & (2n) & 1.2 (1) & $0.2-2.2$ & & \\
\hline G4702 & $(4 n)$ & $1.5 \quad(26)$ & $0.5=2.5$ & & \\
\hline SED & & 0.17 & & & \\
\hline \multicolumn{2}{|c|}{ GD "Mediterranean } & 1.8 & \multirow{2}{*}{\multicolumn{3}{|c|}{$\begin{array}{l}0.7=2.7 \\
0.4=2.4\end{array}$}} \\
\hline G4701, Ci47 & & 1.4 & & & \\
\hline \multicolumn{2}{|c|}{ SED } & 0.14 & & & \\
\hline
\end{tabular}

$\mathrm{O}=$ negligible; 1 = slight, 2 = moderate; $3=$ severe. Values in parenthesis refer to rankings for damage relative to all Lotus accessions $(1=$ best; $55=$ poorest $)$.

combined high yields (Table 3 ) and high spread (Table 5) at any one site, none did so at all three sites, and only S1928 (Chile) did so at two sites (Waipori and Ailsa Craig).

While temperature declines relatively uniformly with increasing altitude, plant diameter decreased markedly from the middle to high compared with the low to middle site (Table 5). Mean plant diameter was barely one-third as high at the highest site as at the lowest.

\section{CONCLUSIONS}

G4701 has shown the best overall combination of productivity, spread and frost tolerance among all 55 accessions. Its tetraploid equivalent, G4702, has more rapid germination at low temperature (Table 2), higher seedling vigour (Barclay \& Lambert 1970) and will likely give greater ease of establishment compared with the diploid. One of the low temperature germination selections from within Maku (selection 1) has also shown good productivity, and frost tolerance not significantly lower than 
Table 5: Mean diameter of Lotus pedunculatus plants (m), autumn 1986.

\begin{tabular}{|c|c|c|c|}
\hline \multirow[t]{2}{*}{ Cultivar or line } & \multicolumn{3}{|c|}{ Mea" plant diameter (m) } \\
\hline & $\begin{array}{l}\text { Waipori } \\
(460 \mathrm{~m})\end{array}$ & $\begin{array}{l}\text { Castle Dent } \\
(750 \mathrm{~m})\end{array}$ & $\begin{array}{l}\text { Ailsa Craig } \\
(1040 \mathrm{~m})\end{array}$ \\
\hline Maku & $1.40(47)^{\prime}$ & $0.71(54)$ & $0.48(47)$ \\
\hline Selection 1 & $1.44(46)$ & $0.74(53)$ & $0.45(49)$ \\
\hline Selection 2 & $1.19(52)$ & $0.75(52)$ & $0.32(54)$ \\
\hline G4703 & $1.47(44)$ & $0.91(48)$ & $0.43(51)$ \\
\hline G4704 & $1.03(55)$ & $0.61(55)$ & $0.31(55)$ \\
\hline G4701 & $1.54(40 \Rightarrow)$ & $0.97(44)$ & $0.47(48)$ \\
\hline G4702 & $1.38(48)$ & $0.92(47)$ & $0.56(35)$ \\
\hline SED (for all 55 crs \& lines) & 0.16 & 0.14 & 0.08 \\
\hline GD "Mediterranean" & 1.31 & 0.74 & 0.40 \\
\hline G4701 \& 4702 & 1.46 & 0.94 & 0.52 \\
\hline SED & 0.11 & 0.09 & 0.04 \\
\hline Grasslands cultivars (7) & 1.35 & 0.80 & 0.43 \\
\hline Other cultivars \& lines (48) & 1.70 & 1.28 & 0.62 \\
\hline SED & 0.06 & 0.05 & 0.03 \\
\hline Overall mea" & 1.65 & 1.22 & 0.59 \\
\hline Range & $1.01-2.05$ & $0.61-1.62$ & $0.31 \cdot 0.89$ \\
\hline
\end{tabular}

'Values in parenthesis refer to ranking for plant diameter, 1.55 .

the best lines. The use of these cultivars or selections is likely to enhance the role of lotus in tussock grassland pasture systems. Considerable progress has been made in more precisely defining those landscape units and pastoral systems where Lotus pedunculatus performs better than alternative legumes. This approach, together with improved establishment and management practices will ensure that the inherent limitations of lotus are minimised and its attributes capitalised on more effectively.

Acknowledgements

D.J. Scott and D.D. Bell for supplying data on low temperature germination

\section{References}

Armstrong C.S. 1974. Grasslands Maku tetraploid lotus. NZ Journal of Experimental Agriculture 2: 333-336.

Barclay P.C., Lambert J.P. 1970. The breeding and testing of Lotus pedunculatus Cav. in New Zealand. Proceedings XI International Grassland Congress: 278-281.

Charlton J.F.L. 1978. Establishment of pasture legumes in North Island hill country II. NZ Journal of Experimental Agriculture 5: 385.390

Dunbar G.A., Costello E.J. 1985. Persistence and growth of Maku lotus on contrasting aspects at high altitude. Proceedings NZ Grassland Association 46: 103-I IO.

McIntosh P.D., Enright P.D., Sinclair A.G. 1984. Fertilisers for lotus and clover establishment on a sequence Of acid soils on the east Otago uplands. NZ Journal of Experimental Agriculture 12: 119-129.

Scott R.S., Mills E.G. 1981. Establishment and management of Grasslands Maku lotus in acid, Jow-fertiljty tussock grasslands. Proceedings NZ Grassland Association 42: 131.141.

Wedderbum M.E., Lowther W.L. 1985. Factors affecting establishment and spread of Grasslands Maku lotus i" tussock grasslands. Proceedings NZ Grassland Association 46: 97-101. 